\title{
They made "a mistake" in Job, 4, 11; why not also in Prov, 30, 30? Implicitly, about limits in philology and the necessity of accepting them
}

\author{
Adina Chirilă* \\ Faculty of Letters, History and Theology, West University, Bd. Vasile Pârvan 4, 300223 Timişoara, Romania
}

\begin{abstract}
Article info
History:

Published April 27, 2018

Key words:

philology

historical lexicology

historical semantics

biblical text

translation
\end{abstract}

Received November 7, 2017

Accepted November 20, 2017

\begin{abstract}
The existence of the Greek term $\mu \nu \rho \mu \eta x o \lambda \varepsilon ́ \omega \nu$ in $J o b, 4,11$, in the biblical text of Orthodox tradition, on the steadfast line of the Septuagint, has seemed-time and again-bizarre, and has intrigued enough as to be approached as a textological problem in several articles and studies, some of them extended and well documented, during the last hundred years; it seems that we face an ordinary translation mistake: the Hellenised Hebrew translator of the Septuagint has missed the equivalent of the Heb. ל2 (layish [lah'-yish]) 'a lion' from the original story of Job, and has produced, consequently, what appears to be a hapax legomenon in the sacred text, an odd and obscure term. Reopening the case, the present study argues in favour of a different reading of the word $\mu \nu \rho \mu \eta x o \lambda \varepsilon \dot{\varepsilon} \omega \nu$, which precludes the translator's presumed mistake. Moreover, it reminds the researcher of the necessity to question, in a lucid manner, the arguments that seem to support a certain conclusion.
\end{abstract}

\section{An unexplained "mistake"}

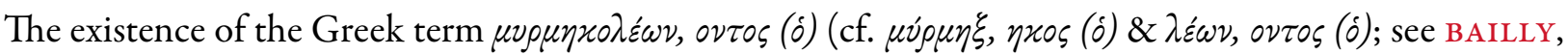
s.v.; LIDDELL-SCOTT, s.v. $\mu v \rho \mu \eta x-$; Engl. antlion; Rom. furnicoleu) in Job, 4, 11, in the biblical text of

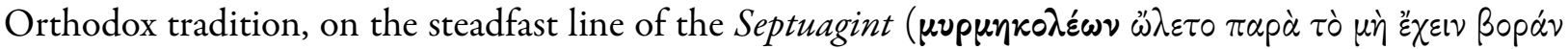

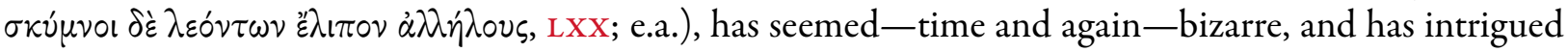
enough as to be approached as a textological problem in several articles and studies, some of them extended and well documented, during the last hundred years (Druce, 1923; Kevan, 1992 ${ }^{1}$; Cardell, 2013; Munteanu, 2016). The usual conclusion concerning the cause of its presence in a context that suggests as normal the option for lion-both from the point of view of the symmetry of the verse (cf. the second part:

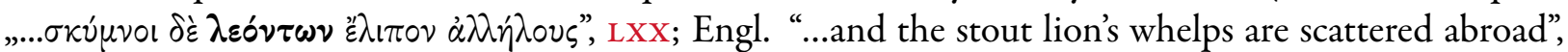
KJV; Rom. „...şi puii leoaicei se risipesc”, в 2008; е.a.), and from the point of view of the immediate logic of the text-is that we face an ordinary translation mistake: the Hellenised Hebrew translator of the Septuagint has missed the equivalent of the Heb. לִ (layish [lah'-yish]) 'a lion' (sTRONG, s.v.), from the original story of Job (see STRONG, s.v. Job, 4, 11, interlinear: Hebrew), and has produced, consequently, what seems to be a hapax legomenon in the sacred text, an odd and obscure term.

The explanation is unsatisfactory. One may ask, how could such a considerable wandering from the form, and, potentially (a potential reached indeed, as it looks from the millenary exegeses of the text in question), from the simple and clear content of Job, 4, $11^{2}$ (cf. ["The old lion perisheth for lack of prey, and the stout lion's whelps are scattered abroad", KJv])?

\footnotetext{
*Email address: chiriladina@yahoo.com.

${ }^{1}$ Unfortunately, this study, extensively cited in the majority of the works that address the problem discussed here, has not been accessible to us.

${ }^{2}$ For the explanations concerning the semantics of the Hebrew terms present in the verse, see STRONG, loc. cit., and also www.blueletterbible.org.
} 
Adina Chirilă

\section{A necessary semantic re-evaluation}

\subsection{Premises}

There are numerous cases when, on one hand, having lost the contact with the world on the realities of which the original Hebrew discourse has been established, being unable to recuperate the knowledge about that world, and, on the other hand, feeling that he has a duty toward his contemporary reader, the translator "betrays" the source-text: either by a) making a plane mistake (he confuses the terms, attributes to them meanings that they do not have, and, consequently, translates them incorrectly into Greek); or by b) choosing what he things to be the most plausible equivalent of a Hebrew word in Greek, but knowing that he could be wrong; or by c) employing standard equivalents, since he usually practices a stereotypical translation, unconcerned about the possibility of being in error; or by d) taking the liberty to correct or to clarify the text, according to his own understanding and to the understanding of his public. ${ }^{3}$. Accordingly,

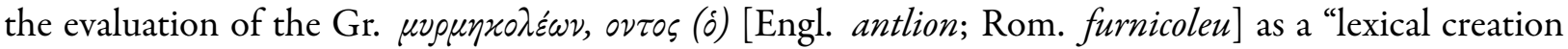
stemming from confusion" ${ }^{4}$ (Munteanu, 2016, p. LXVI; our transl.), in Job 4, 11, is not necessarily strident, but in agreement with the normality of a text's transfer between two languages and, to some extent, two cultures that are wide apart. However, the generalization does not serve the truth, and the researcher cannot give the final judgement on an issue by dint of a single piece of evidence, especially when that piece of evidence is conjectural.

The Heb. (layish [lah'-yish]) '(a) lion; the (old) lion' knows only two occurrences in the biblical text (Job, 4, 11 and Prov, 30, 30), and, as רָ רָ' (walayish [wā. lah'-yish]), one more (Is, 30, 6) (strong, s.v., Englishman's Concordance). On the other hand, the whole corpus of Hebrew writings that would

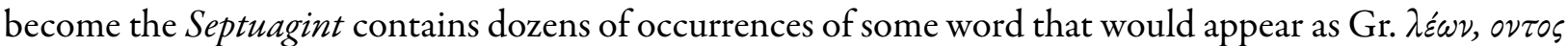
(o) (or as a term designating an animal of the same species), which sustains the idea that the Hebrew word in discussion is a "rare" one (Munteanu, 2016, p. LXVI), and, as a consequence, susceptible of being unrecognisable and unrecognised. Nevertheless, it doesn't cause any problems elsewhere, in Prov, 30, 30 :

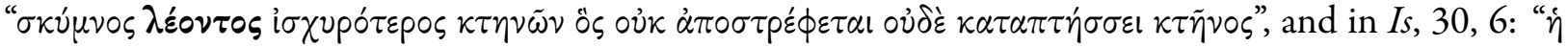

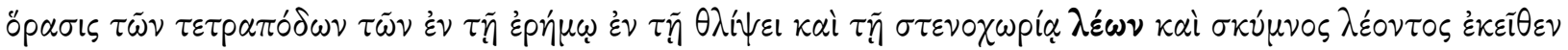

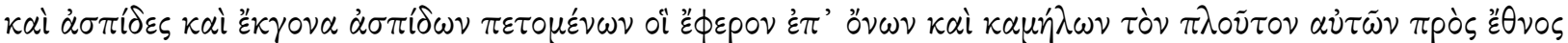

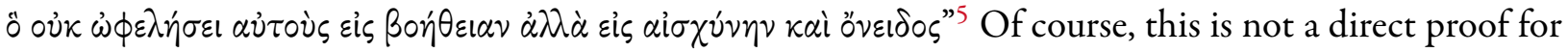

\footnotetext{
${ }^{3}$ See, among others, Joosten $(2016,2014,2010 a)$. For the same matter, concerning however mainly the translation of biblical texts into Romanian, in different epochs and from different sources (Latin, Greek, Slavonic, Hungarian), see Gafton (2012, 2009), Chirilă \& Gafton (2016), Chivu (2009), Jinga (2007), Gheție (1970).

${ }^{4}$ The statement says implicitly that the denotative meaning of the terms is the one we find now in Rom. leul furnicilor (Myrmeleon fornicarius L.; cf. Formicaleon tetragrammicus L.): „,insectă răpitoare cu corpul subțire și lung de c. $4 \mathrm{~cm}[\ldots]$. Larva insectei face o gropiță în formă de pîlnie în nisip, unde stă ascunsă și mănîncă insectele care cad în ea” (MDE, s.v. Leu ${ }^{1}$; cf. DLR, s.v. Leu, $4^{\circ}$ ); for entomologic details, see Ionescu \& Lăcătușu (1971, p. 336-338). Cf. “(family Myrmeleontidæ), any of a group of insects (order Neuroptera) that are named for the predatory nature of the larva, which trap ants and other small insects in pits dug into the ground. (...). The antlion larva digs a funnel-shaped pit (from 2.5 to $5 \mathrm{~cm}$ [ 1 to 2 inches] deep and 2.5 to 7.5 $\mathrm{cm}$ [ 1 to 3 inches] wide at the edge) by using its oval, sandy-gray abdomen as a plow and heaping the loosened particles on its large square head and throwing them clear of the pit. When the pit is completed, the larva buries itself so that only its jaws project. Any small insect that ventures over the edge of the sandy pit slips to the bottom and is seized by the sickle-like jaws of the antlion..." (www.britannica.com).

${ }^{5}$ Noticing the anomaly, Druce (1923, p. 15) discusses the possibility that, for Job, the translators of the Septuagint might have used a Hebrew manuscript that contained, in 4, 11, a different word than that existing in Prov and in $I s$. This situation would also explain, according to the same author, the fact that Jerome, in his Latin Vulgate, chose the noun tigris, for Job, 4, 11, varying his options for Job, Prov, and Is, precisely as they had done with the Septuagint: tigris - leo - leo. This hypothesis cannot be dismissed; but then, the term that might have existed in Job, 4, 11, instead of [lah'-yish], now lost, might have been different from all the other Hebrew terms employed with the meaning 'lion' in the OT, and correctly translated by the LXx: (1.) Gor (Gen, 49, 9; Ier, 51, 38, etc.); (2.) Kephir (Jud, 14, 5; Iv , 4, 10; Ps, 91, 13; 104, 21; and, figuratively, in Ps, 34, 10; 35, 17; 58, 6; Ier, 2, 15) ; (3.) 'Ari (Num, 23, 24; $2 \operatorname{Sam}, 17,10$, etc.); (4.) Shahal (Iv, 4, 10; Ps, 91, 13; Pr, 26, 13; Os, 5, 14); (5.) Labi (Gen, 49, 9; Num, 23, 24; 24, 9; Eze, 19, 2; Na, 2, 11).
} 
the impossibility of an actual confusion in Job, $4,11^{6}$; but there is no evidence for the existence of some linguistic, contextual and co-textual conditions that would favour the confusion: i.e. some situation of homonymy, paronymy, or the proximity of a perturbing term, etc.

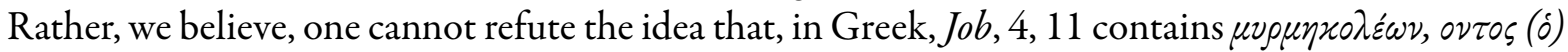
as the proper equivalent for the Heb. לַי (layish [lah'-yish]), with a meaning close to the meaning of the original word, in the original source-text..

Should this be the case, one needs to re-examine the semantic evaluation of the Greek term: Is it possible it refers, in the spirit of the Hebrew text, to a creature whose distinctive physical features ([+ QUADRUPEDAL], [+ MAMMAL], [+ PREDATOR]) are common to those of the unequivocal lion?

The Greek zoonymy does not seem to support this hypothesis.

However, as is known, several Antique writers ${ }^{7}$ record the existence, in some place (India, Ethiopia, Mesopotamia...), of an animal in the description of which appear several elements that, as they pass from one text to another, along the centuries, converge toward the possibility that the consciousness of some readers living in the Ptolemaic epoch grasp the notion of an extra-linguistic reality that goes by the Greek name $\mu \nu \rho \mu \eta x o \lambda \varepsilon \dot{\varepsilon} \omega \nu, \operatorname{ov\tau o\zeta ~(\delta ),~from~the~lexical~field~of~mammals,~sharing~with~} \lambda \dot{\varepsilon} \omega \nu, o \nu \tau o \zeta(\delta)$ a few substantial semes.

Herodotus:

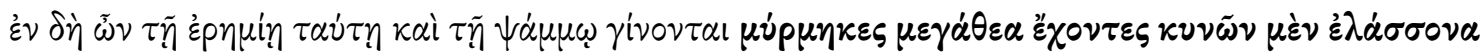

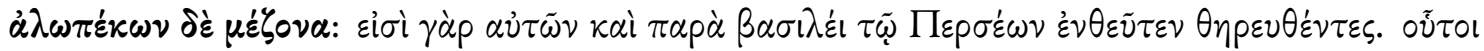

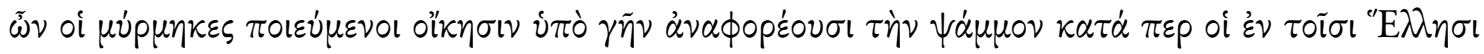

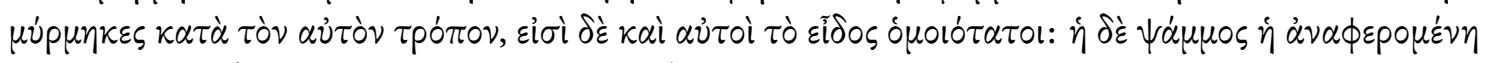

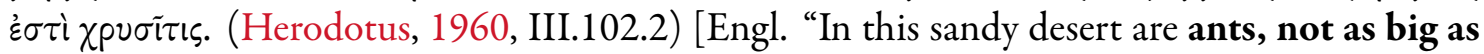
dogs but bigger than foxes; the Persian king has some of these, which have been caught there. These ants live underground, digging out the sand in the same way as the ants in Greece, to which they are very similar in shape, and the sand which they carry from the holes is full of gold.", Herodotus, 1920, III.102.2; Rom. „Prin întinderile pustii și nisipoase forfotesc niște furnici, ceva mai mici decît cîinii, dar mai mari decît vulpile. La curtea regelui Persiei pot fi văzute cîteva, prinse la vînătoarea de aici. Aceste furnici, săpîndu-şi casa sub pămînt, ridică grămezi de pămînt, așa cum fac și furnicile din Ellada și în același chip; la înfățișare seamănă foarte mult cu cele din Ellada. Nisipul ridicat de ele este amestecat cu firişoare de aur.", Herodot, 1961, III.CII, p. 272] (e.a.);

Agatharchides:

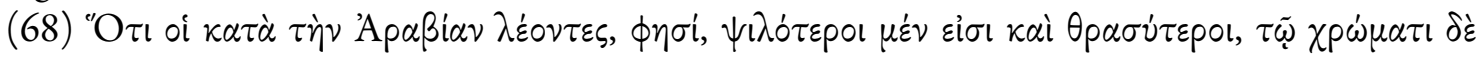

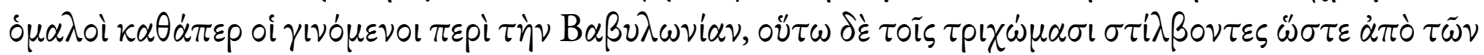

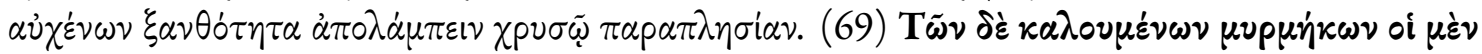

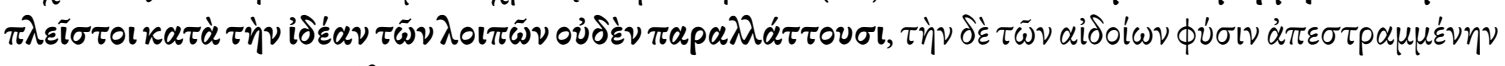

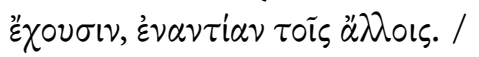

(68) Arabiæ leones minus hirsuti et ferociores sunt, colore autem æquali, sicut illi quos fert Babylonia, pilisque usque adeo rutilis, ut cervicum jubæ auri instar refulgeant. (69) Myrmecoleonum, quos vocant, plerique specie a cæteris nihil differunt; genitalia tamen his sunt aversa, contra quam aliis. (Agatharchides, 1855, p. 158) (e.a.);

\footnotetext{
${ }^{6}$ For what causes various types of error in translation, when the translator cannot be accused of not knowing the language he translates from, see Gafton (2012); for a case study, see Chirilă (2012).

${ }^{7}$ We refer here only to those writings which contain details of interest concerning the problem in discussion; the authors are listed chronologically, till around the translation of the Septuagint: Herodotus ( $5^{\text {th }}$ c. BC), Agatharchidis $\left(2^{\text {nd }}\right.$ c. BC), Strabo $\left(1^{\text {st }}\right.$ c. BC $)$, Aelian $\left(2^{\text {nd }}-3^{\text {rd }}\right.$ c. AD); for a larger list of authors who describe the animal, see Druce $(1923$, p. 354-356).
} 
Strabon:

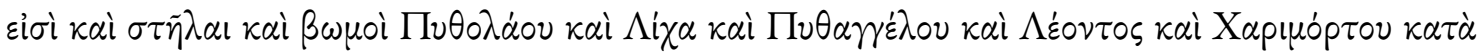

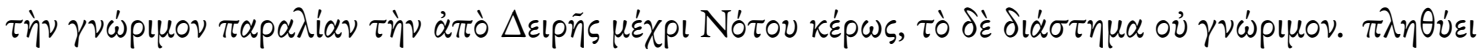

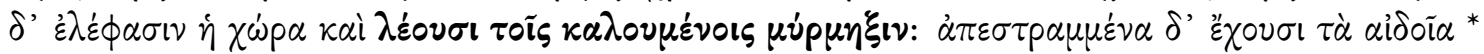

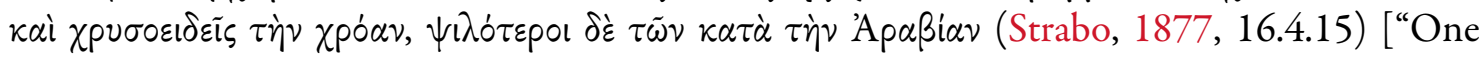
comes also to pillars and altars of Pytholaüs (sic, A.C.) and Lichas and Pythangelus and Leon and Charimortus along the known coast, extending from Deirê as far as Notu-ceras, but the distance is unknown. The country abounds in elephants, and also in lions called ants, which have their genital organs reversed, and are golden in colour, but are less hairy than those in Arabia." Strabo, 1932, XVI.4.15, p. 774] (e.a.);

Aelian:

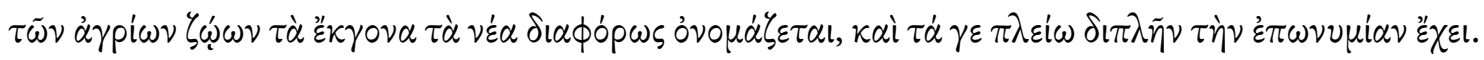

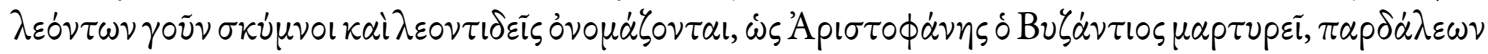

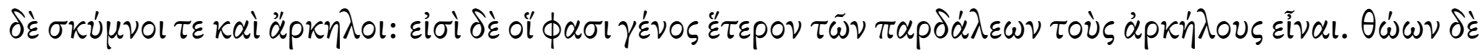

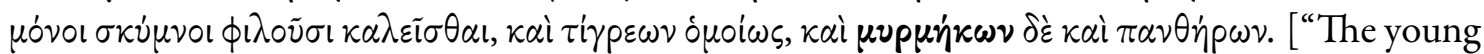
offspring of wild animals have different appellations, and the majority at any rate have two names. The young of Lions, for instance, are called $\sigma \kappa \dot{\nu} \mu \nu \circ \mathrm{l}$ and $\lambda \varepsilon \circ \nu \tau i \delta \varepsilon \tilde{\iota} \varsigma$, as Aristophanes of Byzantium

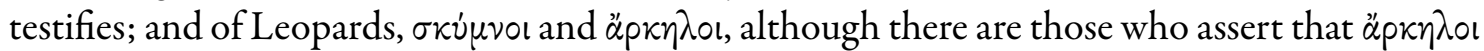
are a different kind of leopard. But the young of Jackals are habitually called $\sigma \kappa v \dot{\mu \nu}$ or only; and the same with Tigers and Ants and Panthers"] (Aelian, 1959, VII.47, p. 162/163) (e.a.).

One can deduce that the Gr. $\mu \dot{v} \rho \mu \eta \xi$, $\eta \varkappa o \zeta(\delta)$ comes to be employed (by dint of some confusion), in a certain context, with the meaning 'a sort of mammal, possibly a predator, possibly a feline', even 'sorte de lion' (BAILlY, s.v.; cf. 'prob[ably] of the lion kind', LIDDELL-SCOTT, s.v., e.a.; „parfois identifié à un lion”, CHANTRAINE, s.v.).

The hypothesis of a zoological confusion-expressed in the notes and the commentaries on some of the aforementioned books - alludes to a terrestrial animal of the Sciuride or Herpestide family (the marmot, the gopher, the mongoose...), whose area covers wide regions in the Middle East, India or Africa, and which produces, by digging, formations resembling the anthills, or which takes soil in underground galleries (see, for Herodotus: Barguet, 1964, p. 1411; Piatkowski, 1961, p. 489; for Aelian: Scholfield, 1959, p. 163). The issue has been approached time and again, and, in striving for the exact identity of the elusive creature, the scholars have followed numerous and various clues, from linguistic ones-observing the form and content of the Mahäbhärata -, to ethnographic ones; the opinions were slightly different, but they converge to the verdict marmot (see a synthesis at Cardell, 2013).

However, we are less interested ${ }^{8}$ in the identity ${ }^{9}$ of the creature that happens to dig gold (see Herodotus, loc.cit.), as known by the human population of that mythical oriental Eldorado. Because, once entered the Greek discursive stream, and being used in a context that remains relatively stable ${ }^{10}$ but upon which tells the consciousness (reasoning) of the receptor, the linguistic sign with which the reader/speaker has to operate is a Greek one, one that has (or receives) or not a certain meaning. The way in which Strabo,

\footnotetext{
${ }^{8}$ And make a mistake they who, working in the field of philology, focus on this matter.

"It even became the subject of a newspaper article: the "New York Times" "solved" the case in Nov. 25, 1996, as as news in brief, citing the French ethnologist Michel Peissel (cf. L'or des fourmis : la découverte de l'eldorado grec au Tibet, Robert Laffont, Paris, 1984; in Engl., The Ant's Gold, discovering the Greek Eldorado, Collins-Harvill, London, 1984), who had studied, on the Dansar plateau, between India and Pakistan, a tribal population-Minaro-whose elders were still picking gold from the hills erected by marmots; unfortunately, the data gathered ethnographically could not be verified ethologically: "Ideally we should make a full archaeological and geological survey in the area. But it's right in the line of fire of both sides. There was gunfire when we were there. The locals tell us that the marmots are dwindling. The Indian soldiers are constantly taking potshots at them" (Peissel, 1984, apud Simons, 1996).

${ }^{10}$ In the present case, the context comprises, as central elements: a faraway land, a narrator endowed with the prestige of the historian, the practice of gold picking.
} 
e.g., employs the term $\mu \dot{v} \rho \mu \eta \xi, \eta x o s(\delta)$, at the end of the $1^{\text {st }}$ c. BC, writing about exotic lands, points out a thorough judgement upon the reading that one should apply to this word, when it is found in a certain (con)text. It is probably improper to state that, by the beginning of the $1^{\text {st }}$ c., Gr. $\mu \dot{v} \rho \mu \eta \xi$, $\eta \varkappa o s(\delta)$ developed a new meaning for the ordinary speaker, forming a case of homonymy still unregistered by dictionaries. But it seems plausible that a certain type of speaker, culturally conditioned, be capable of recognizing in $\mu \dot{v} \rho \mu \eta \xi, \eta \varkappa 0 \xi(\delta)$ the Greek reflex of a foreign linguistic significant whose signified is 'lion', and of activating the association $\mu \dot{v} \rho \mu \eta \xi$, $\eta$ ros $(\delta)$ - 'lion', in a context similar to that that generated it at some point.

In many a respect, a similar case we find with Gr. hippo(potamos): in certain contexts, it shows the same willingness of the speaker to ignore the normal Greek signified of the word and to accept the signified it has received bookishly: following, perhaps, a confused usage of a local term designating a specific animal, hippos (Diodorus Siculus- $1^{\text {st }}$ c. BC-uses it without the

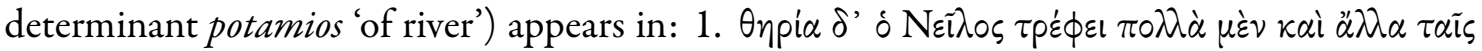

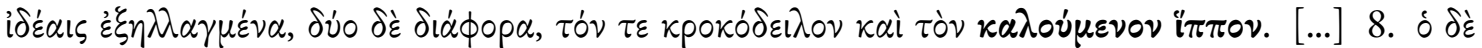

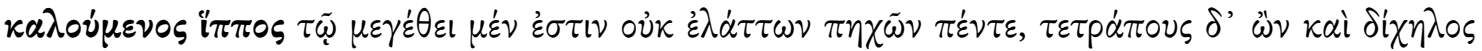

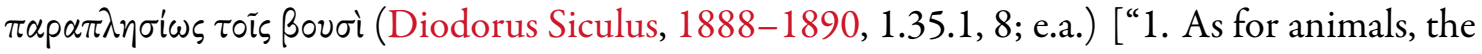
Nile breeds many of peculiar form, and two which surpass the others, the crocodile and what is called the 'horse.'/.../ 8. The animal called the 'horse' is not less than five cubits high, and is fourfooted and cloven-hoofed like the ox" (Diodorus Siculus, 1933, 1.35.1, 8)]. Cf. the Romanian version, which, by favourizing the option hipopotam [Engl. hippopotamus], wanders from the original form and obscures the double designation of the Gr. word hippos: „1. Nilul hrănește multe animale cu înfățişări felurite, între care două specifice fluviului: crocodilul și hipopotamul. [...] 8. Hipopotamul e lung de cinci coți. El este un patruped cu copitele crăpate, aducînd cu ale boului" (Diodor din Sicilia, 1981, 1.XXXV.1, 8, p. 49-50).

Unfortunately, the claim does not escape the spectrum of hypotheses. Yet, we express it, for it argues for the competence of the translators of the Septuagint, not as lacking in intellectual ability and translating skills as we might think now, after more than two millennia of perpetually accumulated experience, knowledge, and lexicological bibliography. ${ }^{11}$.

\subsection{Other premises, and what follows from there on lexical level}

The Hellenized Hebrew translator needed a "rare" word, like the one he found in the text he was translating, that would have indicated 'a sort of lion', in a story whose dramatical action took place somewhere outside Israel, in a land how vague so ennobled due to the value of the moralizing story of Job, and whose descriptive and distinctive features, therefore, had to be preserved as such. Judging by the theme and the style of the Book of Job, the mythical land $U z(J o b, 1,1)$ is located somewhere in a vast area that includes Egypt, Mesopotamia, the south of Edom and the northern region of the Arabic Peninsula (Seow, 2013 , p. 61, 314, 496, 702) - the area where, according to some of the ancient writers, lives the legendary

\footnotetext{
${ }^{11}$ Studying thoroughly the matters concerning the translation of idiomatic expressions from Hebrew into English, Joosten (2010a) grasps the remarkable position of the Seventy in relation both to the source-language, and to the target-language: "on the whole, the Greek translators's grasp of the source language was excellent. Of course, the meaning of one or another Hebrew expression may indeed have been forgotten by the Hellenistic period. But on the whole, the translators understood the idiomatic expressions well enough: literal renderings are not to be attributed to a lack of understanding” (p. 66; e.a.); and: „The way the translators dealt with idiomatic expressions also reveals something of their deeper motives. The translators brought great creativity to their project. Their objective, however, was not to create something new and unprecedented, but to preserve the old. To all appearances, the ultimate goal of the translators was to give to their readers as much as possible of what they found in the source text. Although the translational process sometimes demands that one should abandon either the wording of the source text or its global meaning, the Seventy were not at ease with this alternative. More often than not, they refused this basic dilemma and tried to compose in Greek an expression that paid tribute to both the wording and the sense. Although some of their renderings are open to criticism, because they follow neither the form nor the meaning of the source, they reflect much intelligence and a general preparedness to try out new formulas" (p. 68; e.a.).
} 
$\mu \dot{\rho} \rho \mu \eta \xi$. However, had the translator simply used $\mu \dot{v} \rho \mu \eta \xi, \eta \varkappa o \zeta(\delta)$, he would have caused perplexity to the common reader, who would have thought spontaneously of the meaning 'ant'; or, a noun compound of two elements that were essential in that particular context, appeared as the perfect solution, both for the atmosphere of the original text, and for the new reader: * $\mu \nu \rho \mu \eta x o-\lambda \varepsilon \dot{\varepsilon} \omega \nu$ (lit. ant-lion), the second element functioning as a clarifying synonym of the first element, the expected "reading" being: 'the ant in the sense of 1 i o n...' (or 'the ant which is actually a $\mathrm{l}$ i o n'), according to the logic of the whole verse.

In terms of form, the word belongs to a class of compound zoonyms quite common in the Hellenistic epoch and in later Greek (Bodson, 2005, p. 463): hippo-tigris, lit. „horse-tiger”; hipp-elaphos, lit. „horsestag”; kamelo-pardalis, lit. „camel-leopard/panther”; stroutho-kamelos, lit. „bird-camel”, etc. But it doesn't necessary follow and it is not equally clear that it shares the same semantic substance with the aforementioned examples. In hippo-tigris,one recognizes a model in which "the names of two animals are placed side by side to identify a third one primarily seen by the ancient people as sharing some morphological and often behavioural traits with both of them" (Bodson, 2005, p. 463), namely: 'a horse with ti g e r-like stripes' (i.e., zebra), 'a camel with le o pard-like patches' (i.e., giraffe), 'a bird that looks and runs like a c a m el' (i.e., ostrich), etc. Such name inspiring descriptions occur in the presence of the animal that has to receive a name, and the namer knows well the aspect and behaviour of the three creatures involved in the process; moreover, numerous sources depicts the namee, and justify the chosen name in a particular case. ${ }^{12}$. Or, concerning the $\mu \nu \rho \mu \eta \varkappa 0-\lambda \varepsilon \dot{\varepsilon} \omega \nu$, if we were to accept this paradigm (the first element of the compound name indicates the genus, and the second element, the species, Bodson, 2005, p. 463) ${ }^{13}$, we would expect to find among the texts of the period one or more sources confirming the existence and describing the appearance of an actual creature that seems to be an ant (or, perhaps, an insect) with some characteristics of a lion ([+ ROBUSTNESs], [+ AGGRESSIVENESS], [+ FEROCITY], [+ PREDATORY TECHNiQUe]), a creature that has been wrongly perceived as being designated by the Heb. [lah'-yish]. This doesn't happen but several centuries later, when, in the $6^{\text {th }}$ and $7^{\text {th }}$ c., and, more obviously, beginning with the $9^{\text {th }} c$., scholars like Gregory the Great, Rabanus Maurus, Albertus Magnus and Thomas of Cantimpré (the two

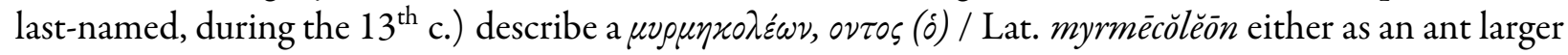
than other ants, or as a particularly aggressive ant, that feeds on regular ants, or, finally, as a larva that feeds on the ants that slip to the bottom of its sandy trap. ${ }^{14}$.

The interval of almost a millennium between the attestation (probably, creation, as well ${ }^{15}$ ) of the Gr. in the Septuagint, and its first employments with the meaning it has today, raises a question concerning

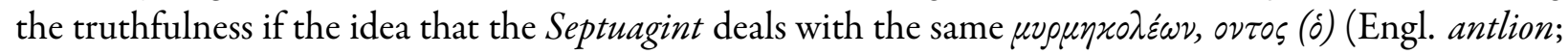
Rom. furnicoleu/leul furnicilor) we find in nowadays entomology.

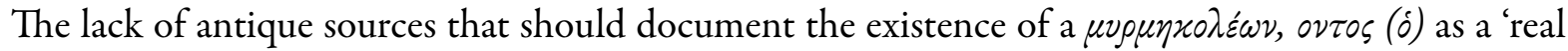
insect' (see supra, note 4) hinders also the idea that, at the beginning of the $2^{\text {nd }}$ millennium - after the late Antiquity and the Middle Ages in which various exegetes, the Physiologus and the Bestiary had created and popularized exclusively the image of a fabulous creature by the name of $\mu \nu \rho \mu \eta x o \lambda \varepsilon \varepsilon \nu$-, scholars like Albertus Magnus did not achieved but a mere rediscovery of the original meaning of the word.

\footnotetext{
${ }^{12}$ See Bodson (2005). For camelopardalis (Rom. camelopard 'giraffe'), in particular, see Buquet (2006, 2008).

${ }^{13} \mathrm{Cf}$. the reading/understanding suggested by the form (Rom.) leul-furnică (Engl., lit. 'lion-ant'), where the creature in question seems to refer to a small lion species: „leul-furnică a pierit fiindcă nu mai avea de mâncare, / iar puii leilor s-au risipit care-ncotro" (Septuaginta 4/II, 2007, Iv , 4, 11; trans. from Greek by Iulia Cojocariu, Francisca Băltăceanu, and Monica Broșteanu).

${ }^{14}$ Quite accurate is Albertus Magnus' description: “It is not an ant as some maintain. For I have frequently observed and often pointed out to friends that this creature is similar in form to a tick. It conceals itself in sand, digging a hemispherical cavity, one pole of which is its mouth. When ants pass by gathering food, it catches and devours them. I have observed this repeatedly. In winter, they are said to plunder the food stocks of ants, because in summer, they themselves do not lay in stores of food" (apud Klausnitzer, 1987, p. 129).

${ }^{15}$ Without exception, all dictionaries and other lexicographical works refer to the Septuagint, Job, 4, 11, with no reference to a different text from the same period. The statement that Agatharchides, in the $2^{\text {nd }} \mathrm{c}$. $\mathrm{BC}$, writes about the antlion using its Greek name (Druce, 1923, p. 8) is false: cf. Agatharchides (1855, p. 158; cf. Müller’s note, \$68).
} 
The phenomenon is known for kamelo-pardalis (Buquet, 2006, 2008), stroutho-kamelos (Bodson, 2005,

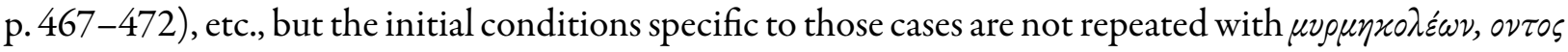
(o)!

As it happens with the "clarification" of the other compound names of animals, the Oriental patristic literature, the Physiologus and the Bestiary see $\mu \nu \rho \mu \eta x o \lambda \varepsilon \omega \nu$ as an animal of double nature: with the body of an ant, and the head of a lion, that can feed neither on grains-because it is also a lion-, nor on meatbecause it is also an ant; consequently, and conveniently, the exegeses speculates it moralizingly. However, by dint of their word, one cannot conclude that what goes by the name $\mu \nu \rho \mu \eta x o \lambda \varepsilon \omega \nu$ is, in itself, and along the centuries, "a fantastic animal from the Medieval bestiary, without a real existence" (Munteanu, 2016, p. LXIV; e.a., our trans.), and cannot find out either "what is, in fact" the antlion (idem, p. LXVII; e.a., our trans.), because: a) to a great extent, texts as such are formed circularly; b) it is highly possible that the described morphology of an animal might reflect a superficial etymological analysis/the superficial formal level of the word in question, many ears after its first occurrence in a text (in a case of folk etymology); c) the animal morphology itself finds justification in the importance one assumes it has in formulating and supporting certain spiritual precepts.

The last observation might suggest that $\mu \nu \rho \mu \eta x o \lambda \varepsilon \dot{\omega} \omega \nu$ presents, in fact, a case similar with that of some compound animal names that occur in Greek literature anterior to Septuagint, that display the same structure, and which do not designate real living creatures: e.g. kunamuia lit. 'dog/bitch-fly', or kunalopex lit. 'dog-fox', but describe metaphorically a human type, i.e. "the annoying impudent" and "the impertinent"... Likewise, it is-one may say-possible that the inspired translator of the book of Job might have wanted to (re)create the image of a "hypocrite", of someone whose existence, because he/she is two things simultaneously, cannot be but denied ${ }^{16}$ by a lucid authority... (see the often made connection between Job, 4,11 and $M t, 5,37)$. And yet, at Homer and Aristophanes, the naming follows the need to characterize, and nothing suggests a different state of situation; while in the case of the Gr. $\mu \nu \rho \mu \eta x o \lambda \varepsilon \dot{\varepsilon} \omega \nu$, the figurative interpretation, and, consequently, the characterization of the human nature follow the finding of the word, under the imperious need to give sense (a particular ${ }^{17}$ sense!) to the text.

On the other hand, it seems to us that there is an apposite similarity, although partial, between the case of $\mu \nu \rho \mu \eta x o \lambda \varepsilon \varepsilon^{\omega} \nu$ and the case of another compound name, tragelaphos lit. 'goat-stag', which, at some point, lost the meaning of 'fabulous animal/unnatural monster', that it had had at Aristophanes, in the $5^{\text {th }}-6^{\text {th }} c$. $\mathrm{BC}^{18}$, and found a place in the semantic field of the natural fauna (BAILLY, s.v. $\tau \rho \alpha \gamma \dot{\varepsilon} \lambda \alpha \varphi \circ \zeta, 0 v$, (o) 2.: post. 'sorte de gazelle ou d'antilope à barbe de bouc'), of the "natural monsters" like the kamelo-pardalis that we find at Diodorus Siculus, in the $1^{\text {st }}$ c. BC:

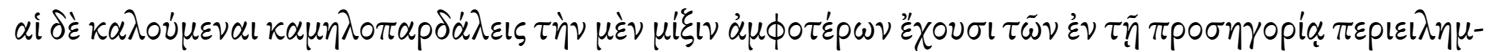

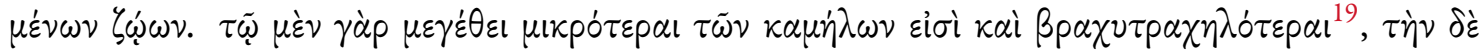

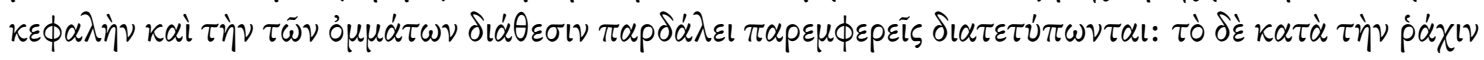

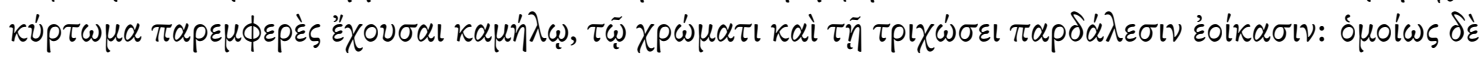

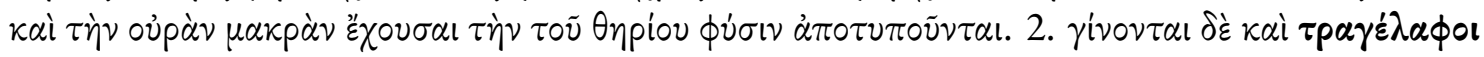

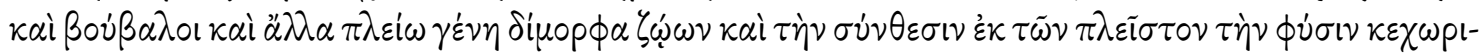

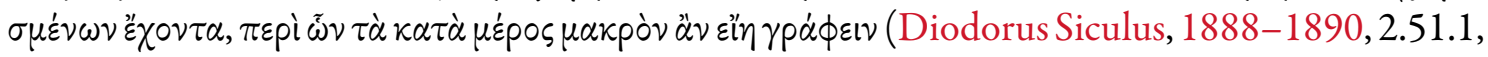

\footnotetext{
${ }^{16}$ Cf. Chrysostome (1988, I, p. 228/229), who sees in the persistence of a dual creature, that cannot feed and sustain itself, the opposite, namely precisely the grace of God!

${ }^{17}$ It has been pointed out the "ingenious" (Munteanu, 2016, p. LXVI) interpretation given to the $\mu \nu \rho \mu \eta x o \lambda \varepsilon \dot{\varepsilon} \omega \nu$ [Rom. furnicoleu] by Bartolomeu Anania, who makes use of the Romanian folk entomological nomenclature: "In order to underline the power of God, the only one that regulates everything in the world (v. 9), in verses 10 and 11, the poet comes at first with imposing examples (the lion, the lioness, the monsters), and then he gets down to the small world of insects" (Anania 2001, note on Job, 4, 11; e.a., our trans.).

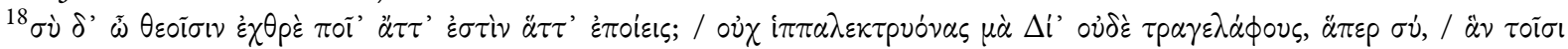

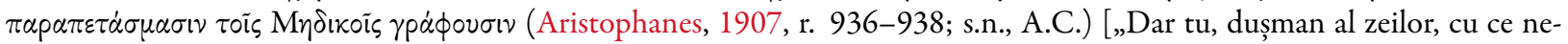
ai pricopsit? / N-am cai-cocoși, țapi-cerbi, / Ca pe covoarele persane!’, Aristofan, 1956, r. 932-934].

${ }^{19}$ Pentru anomalia descrierii unui camelopard 'girafă' cu gîtul mai scurt decît al unei cămile, v. ?, 2.51.1, nota 58.
} 
2; s.n., A.C.) ["The camelopards, as they are called, represent the mixing of the two animals which are included in the name given to it. For in size they are smaller than the camel and have shorter necks, but in the head and the arrangement of the eyes they are formed very much like a leopard; and although they have a hump on the back like the camel, yet with respect to colour and hair they are like leopards; likewise, in the possession of a long tail they imitate the nature of this wild beast. 2 There are also bred tragelaphoi (goat-stags) and bubali and many other varieties of animals which are of double form and combine in one body the natures of creatures most widely different, about all of which it would be a long task to write in detail" (Diodorus Siculus, 1933, 2.51.1, 2; s.n., A.C.)].

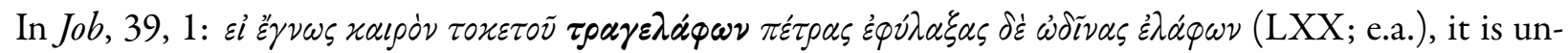
hesitatingly translated as ...goat (or something similar) — a word that refers to an actual creature, plausible in the given context: "Knowest thou the time when the wild goats of the rock bring forth? or canst thou mark when the hinds do calve?" (KJv; e.a.) [Rom. "Ştii tu când nasc caprele sălbatice? Ai băgat de seamă care este vremea cerboaicelor?", в 2008); cf. "S,tii tu sorocu'n care nasc caprele-de-stâncă? ai urmărit tu vremea cerboaicelor când fată?", Anania 2001; e.a.].

\section{Conclusions}

As soon as one analyses them in their contexts, terms like those previously mentioned (myrmex, hippos; hippotigris, etc.; kunalopex, etc; tragelaphos, etc.) support the idea that the semantic life they have or develop is indifferent to the mould they have once assumed; that a certain form does not always dictates the semantic substance of a word; that a form can produce a certain content, according to the needs of the moment and of the translator; that there isn't a unique formula for evaluating the existence and the purpose of a particular word in a text. Therefore, to postulate that the Greek term $\mu \nu \rho \mu \eta x o \lambda \varepsilon \dot{\varepsilon} \omega \nu$, in Job, 4, 11 , is to be related neither to some fabulous creature, nor to the antlion of our entomology book does not have a weaker chance of being true, than the opposite one; but, as we've tried to argue, on the contrary. ${ }^{20}$

\section{References}

Anania 2001 = Biblia sau Sfânta Scriptură. Ediție jubiliară a Sfântului Sinod, (...) redactată și adnotată de Bartolomeu Valeriu Anania, București, Editura Institutului Biblic și de Misiune al Bisericii Ortodoxe Române, 2001.

Aelian (1959). On the Characteristics of Animals. Vol. II, Books VI-XI. With an English Translation by A.F. Scholfield, London - Cambridge, MA.

Agatharchides (1855). Geographi Graeci Minores, ed. Karl Müller, vol. I, Paris.

Aristofan (1956). Broaștele. Traducere de Eusebiu Camilar și H. Mihăescu, in Teatru, ESPLA, București.

Aristophanes (1907). Comoediae, ed. F. W. Hall \& W.M. Geldart (eds.), vol. 2, Clarendon Press, Oxford.

в 2008 = Biblia sau Sfânta Scriptură. Tipărită (...) cu aprobarea Sfântului Sinod, Editura Institutului Biblic și de Misiune Ortodoxă, București, 2008.

BAILLY = A. Bailly, Dictionnaire grec-français, Rédigé avec le concours de E. Egger, Edition revue par L. Séchan et P. Chantraine, Librairie Hachette, Paris, [1950].

Barguet, A. (1964). Notes, Hérodote. Thucydide, OEuvres complètes, Gallimard.

Bodson, L. (2005). Naming the Exotic Animals in Ancient Greek and Latin, in Minelli, Al., Ortalli, G. \& Sanga, G., Animal Names, Instituto Veneto di Scienze, Lettere ed Arti, Venezia, p. 453-480.

Buquet, T. (2006). Pourquoi la Bible des Septante a-t-elle traduit le zemer du Deutéronome en kamelopardalis ? Réflexions sur le statut symbolique et alimentaire de la girafe, in "Anthropozoologica", 41 (1), p. 7-25, [online].

Buquet, T. (2008). La girafe, belle inconnue des bibles médiévales. Camelopardalis : un animal filologique, in "Anthropozoologica", 43 (2), p. 47-68, [online].

Cardell, M. (2013). Marmottes, rats et fourmis. A propos du mystère des fourmis chercheuses d'or qu'Hérodote décrit dans ses 'Histoires' (III, 102-105), in "Connaissance Hellenique”, [online].

\footnotetext{
${ }^{20}$ At worst for us, the issue concerning the story of $\mu \nu \rho \mu \eta x o \lambda \varepsilon ́ \omega \nu$ in $J o b, 4,11$ is one of those that cannot reach a unanimous conclusion! At least, not with the data we have collected so far.
} 
CHANTRAINE = Pierre Chantraine, Dictionnaire étymologique de la langue grecque $:$ histoire des mots, Klincksieck, Paris, 19681974.

Chirilă, A. (2012). Opțiuni de redare a numelor proprii in traducerile biblice. Studiu de caz: numele ficcelor lui Iov (Iov 42: 14), in "Analele științifice ale Universității «Alexandru Ioan Cuza» din Iași”, Secțiunea IIIe Lingvistică, vol. LVIII, p. 33-43.

Chirilă, A. \& Gafton, Al. (2016). Dinamica traducerilor biblice în raport cu ambiguitatea contextuală a termenilor. Studiu de caz: Levitic 11, 22, in “Analele Științifice ale Universității «Ovidius» Constanța”. Seria Filologie, vol. XXVII, iss. 2, p. 169-178.

Chivu, Gh. (2009). De la litera la spiritul textului sacru. Mărturia unui Evangheliar manuscris, in "Text și discurs religios”, vol. II, p. 41-48.

Chrysostome, J. (1988). Commentaire sur Job. Tome I (Chapitres I-XIV). Introduction, Texte critique, traduction et notes par Henri Sorlin, avec la collaboration de Louis Neyrand, Les Éditions du Cerf, Paris.

Diodorus Siculus (1888-1890). Diodori Bibliotheca Historica, Vol 1-2. Immanel Bekker. Ludwig Dindorf. Friedrich Vogel. In aedibus B. G. Teubneri. Leipzig.

Diodorus Siculus (1933). The Library of History. Book I. Loeb Classical Library.

Diodor din Sicilia (1981). Biblioteca istorică. Traducere de Radu Hîncu și Vladimir Iliescu, Editura Sport-Turism, București. DLR = Dicționarul limbii române. Tomul II, partea I, F-I, Imprimeria Națională, București, 1934.

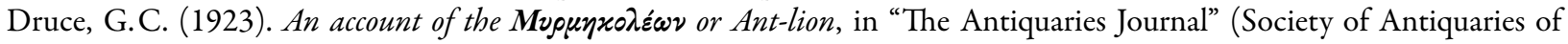
London), vol. III, iss. 4, p. 347-364; ediție digitală: 2004 [online].

Gafton, Al. (2009). Biblia de la 1688. Aspecte ale traducerii, in “Text și discurs religios”, vol. II, p. 49-72.

Gafton, Al. (2012). De la traducere la norma literară. Contribuția traducerii textului biblic la constituirea vechii norme literare, Editura Universității „Alexandru Ioan Cuza”, Iași.

Gheție, I. (1970). Cea mai veche atestare a cuvântului săpun și raportul dintrepsaltirile românești din secolul al XVI-lea, in "Limba română", vol. XIX, iss. 3, p. 247-251.

Herodot (1961). Istorii. Vol. I. Traducere, notițe istorice și note de Adelina Piatkowski \& Felicia Vanț-Ștef, Editura Științifică, [București].

Herodotus (1920). The Histories. With an English translation by A. D. Godley, Harvard University Press, Cambridge.

Herodotus (1960). Historiae. Recognovit breviquue adnotatione critica instrvxit Carolus Hude. Editio Tertia, OXONII e Typographeo Clarendoniano.

Ionescu, M. \& Lăcătușu, M. (1971). Entomologie, EDP, București.

Joosten, J. (2010a). Translating the Untranslatable: Septuagint Renderings of Hebrew Idioms, in Hiebert, R. (ed.), "Translation Is Required": The Septuagint in Retrospect and Prospect, Brill, Leiden / SBL, Atlanta, p. 59-70.

Joosten, J. (2010b). The Aramaic Background of the Seventy: Language, Culture and History, in "Bulletin of the International Organization for Septuagint and Cognate Studies", 43, p. 53-72.

Joosten, J. (2014). Trahir pour mieux traduire. La traduction « contradictoire » dans la Septante, in Frey, D., Grappe, C. \& Wieger, M. (eds), Usages et mésusages de l'Écriture, Presses Universitaires de Strasbourg, Strasbourg, p. 19-30.

Joosten, J. (2015). The Interplay between Hebrew and Greek in Biblical Lexicology: Language, Text and Interpretation, in Bons, E., Joosten, J. \& Hunziker-Rodewald, R. (eds), Biblical Lexicology: Hebrew and Greek. Semantics - Exegesis - Translation, De Gruyter, Berlin, p. 209-223.

Joosten, J. (2016). Septuagint Greek and the Jewish Sociolect in Egypt, in Bons, E. \& Joosten, J. (eds), Die Sprache der Septuaginta/The Language of the Septuagint, LXX.H 3, Gütersloher, Gütersloh, p. 246-256.

Jinga, C. (2007). Traducerile Bibliei - câmp deschis, Editura Marineasa \& Editura Solness, Timişoara.

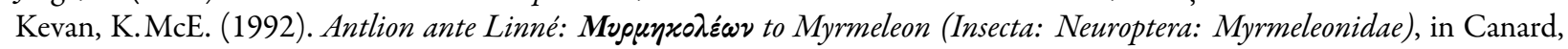
M, Aspöck, H. \& Mansell, M. W. (eds), Current Research in Neuropterology, Toulouse, p. 203-232.

$\mathrm{KJV}=$ The Holy Bible. (...), World Bible Publishers, Inc., [s.l.], [s.a.].

Lungu Badea, G. (2004). Teoria culturemelor. Teoria traducerii, Editura Universității de Vest, Timişoara.

Klausnitzer, B. (1987). Insects. Their Biology and Cultural History, Edition Leipzig.

LIDDELL-SCOTT $=$ Henry George Liddell \& Robert Scott, A Greek-English Lexicon, Compiled by.... A New Edition Revised and Augmented throughout by Sir Henry Stuart Jones, Oxford, [s.a.].

LXX = Septuaginta: SESB Edition, ed. A. Rahlfs \& R. Hanhart, Deutsche Bibelgesellschaft, Stuttgart, 2006.

MDE = Al. Stănciulescu (coord.), Micul dicționar enciclopedic, Editura Enciclopedică, Editura Univers Enciclopedic, București, 2005.

Munteanu, E. (2016). Studiu filologic, la Vechiul Testament - Septuaginta. Versiunea lui Nicolae Spătarul Milescu (ms. 45 de la Biblioteca Filialei din Cluj a Academiei Române). Ediție de text, prefață, notă asupra ediției, introducere, bibliografie, indice de cuvinte și forme, indice de nume proprii de Eugen Munteanu (coord.), Ana-Maria Gînsac, Ana-Maria Minuț, Lucia-Gabriela Munteanu, Mădălina Ungureanu, Editura Universității „Alexandru Ioan Cuza”, Iași, p. XLI-LXXVII.

Piatkowski, A. (1961). Note la Herodot (1961), Cartea a III-a. Thalia, p. 463-495.

Scholfield, A.F. (1959). Notes, in Aelian (1959).

Seow, C.L. (2013). Job 1-21. Interpretation \& Commentary, William B. Eerdmans Publishing Company, Grand Rapids, Michigan/Cambridge, UK.

Septuaginta 4/II = C. Bădiliță et. al. (coord.), Iov. Înțelepciunea lui Solomon. Ințelepciunea lui Iisus Sirah. Psalmii lui Solomon, 
Polirom/Colegiul Noua Europă, București/Iași, 2007.

Simons, M. (1996). Himalayas Offer Clue to Legend of Gold-Digging 'Ants', in “The New York Times”, Nov. 25, 1996, [online]. Strabo (1877). Geographica, ed. A. Meineke, Teubner, Leipzig.

Strabo (1932). The Geography of..., vol. VII, Leob Classical Library: Greek texts with facing English translation by H. L. Jones,

Harvard University Press, 1917-1932.

STRONG = Strong's Concordance, [online]. 